\title{
Eotaxin-2 in sputum cell culture to evaluate asthma inflammation
}

\author{
M.E. Scheicher*, M.M. Teixeira\# ${ }^{\#}$ F.Q. Cunha", A.L. Teixeira $\mathrm{Jr}^{+}$, \\ J.T. Filho* and E.O. Vianna*
}

ABSTRACT: The aim of the present study was to elucidate whether the culture of cells recovered from induced sputum may represent a suitable model to evaluate cytokine and chemokine production by airway inflammatory cells.

Sputum induction was performed in 21 normal subjects and 30 asthmatic patients. A total of 21 out of the $\mathbf{3 0}$ asthmatic patients were taking inhaled corticosteroids, while the remaining nine were steroid-naive asthmatics. The steroid-naive group was evaluated before and after a 14-day treatment with oral prednisone $\left(40 \mathrm{mg} \cdot \mathrm{day}^{-1}\right)$. The supernatant of lysed and centrifuged sputum and the supernatant of sputum cell culture were analysed. Tumour necrosis factor- $\alpha$, interleukin (IL)-8 (CXCL8), IL-1ß, IL-13 and eotaxin-2 (CCL24) concentrations were determined by specific ELISA.

Eotaxin-2 production by cell culture was higher in the asthma group $\left(131 \pm 108 \mathrm{pg} \cdot \mathrm{mL}^{-1}\right)$ than in the control group $\left(36 \pm 41 \mathrm{pg} \cdot \mathrm{mL}^{-1}\right)$ and treatment with oral corticosteroids eliminated this difference. In addition, reduction of eotaxin-2 levels by corticosteroid treatment was greater in cell culture (81.3\% reduction) than in sputum (26.4\%). There was correlation between the decrease in eotaxin-2 production and the decrease in blood eosinophil number and between eotaxin-2 and eosinophils in sputum.

Eotaxin-2 may play an important role in asthma and the response to corticosteroid treatment suggests that analysis of sputum cell culture is relevant as an inflammatory parameter.

KEYWORDS: Asthma, cell culture, inflammatory mediators, sputum, steroid

$\mathbf{A}$ sthma is defined as a chronic lung disease with the following attributes: airflow obstruction that is reversible either spontaneously or with treatment, and airway inflammation and increased airway responsiveness to a variety of stimuli, including cold air, methacholine, hypertonic solution inhalation and exercise [1]. The aetiology of asthma is complex and involves the interaction between genetic factors and environment. The vast majority of the data regarding the pathogenesis of asthma concentrates on atopic asthma and the imbalance between the T-helper cell (Th) type 1 and Th2 phenotypes [2]. Further evidence of an inflammatory response in asthma is the presence of cells and mediators in bronchoalveolar lavage (BAL), sputum and respiratory tissues. Eosinophil recruitment from peripheral blood into the airways is controlled by adhesion molecules and chemokines.

The chemokines are a group of chemotactic cytokines that have been subdivided into four families: CXCL, CCL, CL and CX3CL [3, 4]. Members of the CCL branch include regulated on activation, normal T-cell expressed and secreted (RANTES; CCL5), monocyte chemotactic protein (MCP)-2 (CCL8), MCP-3 (CCL7), MCP-4 (CCL13) and eotaxin-1 (CCL11), -2 (CCL24) and -3 (CCL26). RANTES and MCP-3 and -4 are chemotactic for eosinophils, monocytes and lymphocytes, while eotaxins chemoattract eosinophils, basophils and Th2 lymphocytes [4]. Due to their eosinophil chemotactic properties, these chemokines have attracted major attention in allergic inflammation [5]. Studies conducted in adult asthmatics have shown that RANTES, MCP-3 and -4 and eotaxin- 1 and -2 are implicated in asthmatic reactions [6-10].

In clinical practice, the assessment of airway inflammation and the effect of medication on inflammation is difficult. Subjective assessment of symptoms has often been found to be unsatisfactory for monitoring asthma severity [11]. Measurements of levels of exhaled gases, such as nitric oxide (NO), may be useful but more data are needed to fully evaluate the importance of these markers in assessing airway inflammation in asthma, especially because NO can be
AFFILIATIONS

Depts of *Medicine and

"Pharmacology, University of S.

Paulo Medical School at Ribeirão

Preto, Sãu Paulo,

Depts of ${ }^{\#}$ Biochemistry and

Immunology, Institute of Biological

Sciences, and

+Internal Medicine, Medical School, Federal University of Minas Gerais,

Minas Gerais, Brazil.

CORRESPONDENCE

E.0. Vianna

Pulmonary Division

Dept of Medicine

University of S. Paulo Medical

School at Ribeirão Preto

Av. Bandeirantes 3900

Ribeirão Preto

Sãu Paulo

14048-900

Brazil

Fax: 551636336695

E-mail: evianna@uol.com.br

Received:

August 052006

Accepted after revision:

October 262006

\section{SUPPORT STATEMENT}

This study was supported by grants from the S. Paulo State Government (FAPESP) - Brazil, Grants 02/021942 and 98/10382-6.

STATEMENT OF INTEREST

None declared. 
produced in large amounts in paranasal sinuses and the stomach [11]. Repeated bronchoscopic sampling is not feasible on a large scale. The ability to study inflammation has changed considerably with the development of the induced sputum technique as a research and, increasingly, as a clinical tool [12, 13]. Induced sputum was used for the first time in asthmatic patients in 1992, when PIN et al. [14] adapted the technique used until then for diagnosis of Pneumocystis carinii in patients with HIV. In recent years, sputum induction with a hypertonic saline solution and subsequent processing have been refined as a noninvasive research tool providing important information about inflammatory events in the lower airways.

The technique of cell culture has been especially developed for blood cells in an attempt to reproduce in vitro what happens in vivo. Several studies [15-17] have used the culture of blood cells to examine asthma pathophysiology and the responsiveness to treatment. However, very few studies have employed the culture of sputum cells [18-22]. It is likely that cells from the airways provide better information due to their proximity to the site of asthmatic inflammation. The aim of the present study was to elucidate whether the culture of cells recovered from induced sputum may represent a suitable model to evaluate cytokine and chemokine production by airway inflammatory cells. Thus, the present authors have assessed culture time (viability) and the production of inflammatory mediators from stimulated and nonstimulated, adherent and nonadherent cells in asthmatics and in healthy subjects. The response to corticosteroid treatment was also measured by analysis of sputum cell culture.

\section{MATERIAL AND METHODS Subjects}

In total, 51 subjects were included in the present study. A group of 30 stable asthmatic patients (13 males and 17 females of mean age $41.0 \mathrm{yrs}$ ) were recruited from the asthma clinic of the University Hospital of Ribeirão Preto (University of São Paulo, São Paulo, Brazil). A total of 21 asthmatic patients used regular inhaled corticosteroids (mean daily dose 409.5 \pm $40.1 \mu \mathrm{g}$ budesonide) and were studied in a single visit. This group was denominated the asthma inhaled corticosteroid (IC) group. Nine uncontrolled, untreated asthmatics (on bronchodilator) were studied at two time-points: before (pre-treatment) and after (post-treatment) oral corticosteroid (OC) treatment for 14 days ( $40 \mathrm{mg} \cdot \mathrm{day}^{-1}$ prednisone). This group was denominated the asthma OC group. These patients did not present acute asthma and they were scheduled for prednisone treatment independently of asthma severity. The choice for this treatment was due to research purposes. The variables under study and blood eosinophil counts were determined in these patients before and after treatment. A total of 21 normal volunteers (six males and 15 females of mean age $41.1 \mathrm{yrs}$ ) with forced expiratory volume in one second (FEV1) values $\geqslant 90 \%$ of predicted formed a control group (table 1). Smokers, pregnant females, subjects who had experienced a recent infectious episode or had taken systemic corticosteroids or antihistamine drugs during the previous month were excluded from the patient and control groups.

The diagnosis of asthma was confirmed on the basis of a history of dyspnoea and wheezing with a reversible airflow obstruction characterised by a $15 \%$ increase in FEV1 after inhalation of 200-400 $\mu \mathrm{g}$ albuterol and/or a methacholine provocative concentration causing a $20 \%$ fall in FEV1 $<8 \mathrm{mg} \cdot \mathrm{mL}^{-1}$ [23]. The study was approved by the ethics committee of the University of S. Paulo Medical School at Ribeirão Preto. All volunteers gave informed consent to participate in the study.

\section{Sputum induction and processing}

For the sputum induction and processing, the guidelines suggested by the Task Force on Induced Sputum of the European Respiratory Society [24, 25] were applied. All subjects had an FEV1 $>50 \%$ pred. After pre-medication with 200-400 $\mu \mathrm{g}$ inhaled albuterol, sputum was induced by inhalation of a hypertonic saline $(4.5 \% \mathrm{NaCl})$ aerosol delivered by an ultrasonic nebuliser (Ultra-Neb 2000; DeVilbiss-Sunrise Medical, Somerset, PA, USA). Each subject inhaled the aerosol for four consecutive periods of $5 \mathrm{~min}$ for a total time of $20 \mathrm{~min}$. For safety reasons, the peak expiratory flow (PEF) was monitored every $5 \mathrm{~min}$ and the induction stopped when the PEF fell to the critical value (a $10 \%$ fall from the basal value) or when severe symptoms were observed. If a subject tolerated sputum induction for $<20 \mathrm{~min}$ at the pre-treatment visit, then the duration of sputum induction at the post-treatment visit would be the same as that of the pre-treatment visit. Subjects were told to periodically spit saliva into one container and sputum into another. The sputum was weighed and an equal volume of $1 \mathrm{mg} \cdot \mathrm{mL}^{-1}$ dithiothreitol (DTT; GIBCO BRL, Grand Island, NY, USA) was added. The suspension was shaken in a vortex mixer for a few seconds and incubated in a shaking water bath at $37^{\circ} \mathrm{C}\left(150 \mathrm{cycles} \cdot \mathrm{min}^{-1}\right)$ for $15 \mathrm{~min}$ with aspiration every $5 \mathrm{~min}$ for homogenisation. Centrifugation was performed at $750 \times g$ for $10 \mathrm{~min}$. The supernatant was aspirated and stored. The cell pellet was re-suspended in $1 \mathrm{~mL}$ RPMI-1640 medium containing $300 \mathrm{mg} \cdot \mathrm{L}^{-1}$ L-glutamine, $100 \mathrm{U} \cdot \mathrm{mL}^{-1}$ penicillin $\mathrm{G}, 100 \mu \mathrm{g} \cdot \mathrm{mL}^{-1}$ streptomycin sulphate (GIBCO BRL) and 10\% calf serum. Total cell number and cell viability were determined by the Trypan blue exclusion method in a Neubauer chamber and slides were prepared for differential cell counts by cytospin staining with Giemsa stain. The cell concentration was adjusted to $1 \times 10^{6}$ viable cells $\cdot \mathrm{mL}^{-1}$.

Characteristics of sputum induction are shown in table 1. The asthma IC group had a higher total cell number and the asthma OC group had lower duration of inhalation.

\section{Cell culture}

The cell suspension was then plated at $5 \times 10^{5}$ cells $\cdot$ well $^{-1}$ onto a 48-well plastic culture plate (Nunc Brand Products, Roskilde, Denmark) and allowed to adhere for $1 \mathrm{~h}$ at $37^{\circ} \mathrm{C}$ in $5 \% \mathrm{CO}_{2}$. After this adherence period, the supernatant of every well was aspirated to remove nonadherent cells and the wells were washed twice with $\mathrm{PBS}$ at $37^{\circ} \mathrm{C}$. The cells that were not removed were named adherent cells; they were kept in the same wells and $0.5 \mathrm{~mL} \cdot$ well $^{-1}$ of medium was added. The number and viability of the nonadherent cell population were determined. These cells were re-plated at $1 \times 10^{5}$ viable cells $\cdot$ well $^{-1}$ with $0.2 \mathrm{~mL} \cdot$ well $^{-1}$ in 96-well plastic culture plates (Nunc Brand Products) and stimulated with phytohaemagglutinin (PHA; $10 \mu \mathrm{L} \cdot$ well $^{-1}$; GIBCO BRL). Cells were incubated for $24,48,72 \mathrm{~h}$ or 5 days at $37^{\circ} \mathrm{C}$ and $5 \% \mathrm{CO}_{2}$. 


\section{TABLE 1 Characteristics of the subjects studied}

\begin{tabular}{|c|c|c|c|c|}
\hline & Control & Asthma IC & Pre-treatment & Post-treatment \\
\hline Subjects $n$ & 21 & 21 & 9 & \\
\hline Sex $M / F$ & $6 / 15$ & $7 / 14$ & $6 / 3$ & \\
\hline Age yrs & $41.1 \pm 12.9$ & $48.3 \pm 10.5$ & $30.0 \pm 13.1$ & \\
\hline Inhaled corticosteroid & & 100 & & \\
\hline Bronchodilator & & 100 & 100 & 100 \\
\hline Oral corticosteroid & & & & 100 \\
\hline Sputum weight $\mathrm{g}$ & $6.2 \pm 3.3$ & $7.6 \pm 3.3$ & $6.3 \pm 3.9$ & $6.4 \pm 4.9$ \\
\hline Total cell count $\times 10^{6}$ & $3.3 \pm 3.1$ & $6.3 \pm 3.2^{*}$ & $4.0 \pm 3.2$ & $2.5 \pm 0.8$ \\
\hline Duration of induction min & $19.7 \pm 1.1$ & $18.5 \pm 2.3$ & $13.8 \pm 4.1^{*}$ & $13.8 \pm 4.1^{*}$ \\
\hline
\end{tabular}

Data are presented as mean $\pm S D$, unless otherwise stated. IC: patients treated with inhaled corticosteroid; OC: patients treated with oral corticosteroids during 14 days FEV1: forced expiratory volume in one second; \% pred: \% predicted. *: $p<0.05$

In order to perform differential cell counts of the adherent cell culture, sputum cells were also plated on sterile chambers mounted on Permanox slides with covers (Chamber Slide System; Nalge Nunc International Corp., Napersville, IL, USA). At the end of culture time, the slides with adherent cells were detached from the media chamber. At the end of culture time, nonadherent cells were aspirated and slides were prepared by cytospin staining.

\section{Time-response analysis}

After completion of the culture time, cell viability was determined by the Trypan blue exclusion method and a time-response curve was plotted for adherent and nonadherent cells of asthmatics. The supernatant of cell culture was aspirated and frozen at $-85^{\circ} \mathrm{C}$ for storage until measurement of cytokines.

\section{Lipopolysaccharide response}

The cells were cultured and incubated as previously described. The adherent cells were stimulated with lipopolysaccharide (LPS; $10 \mu \mathrm{L} \cdot \mathrm{well}^{-1}$ ) at the following concentrations (in the culture): zero (negative control), $0.02 \mu \mathrm{g} \cdot \mathrm{mL}^{-1}, 0.002 \mu \mathrm{g} \cdot \mathrm{mL}^{-1}$ and $0.0002 \mu \mathrm{g} \cdot \mathrm{mL}^{-1}$.

\section{Detection of cytokines and chemokines}

The concentrations of chemokines (eotaxin-2, interleukin (IL)-8 (CXCL8)) and cytokines (tumour necrosis factor (TNF)- $\alpha$, IL-1 $\beta$ and IL-13) in induced sputum and cell culture supernatant of asthmatic patients and controls were measured by ELISA (R\&D Systems, Minneapolis, MN and Pharmingen, San Diego, CA, USA).

\section{Statistical analysis}

Data concerning viability and inter-group comparisons are reported as mean $\pm \mathrm{SD}$ and were analysed statistically by Kruskal-Wallis test with Dunn post-test. Intra-group comparisons between stimulated and nonstimulated cells and of change $(\Delta)$ in eotaxin-2 production were performed by Wilcoxon matched-pairs test. Correlations between parameters were calculated by Spearman rank correlation. A p-value of $\leqslant 0.05$ was considered to be statistically significant.

\section{RESULTS}

\section{Characterisation of cell culture}

The first part of the analysis of cell culture was performed in asthmatic subjects (asthma IC group) only. Viability was high and of similar magnitude for adherent and nonadherent cells up to $72 \mathrm{~h}$ of culture. After $72 \mathrm{~h}$, the viability dropped significantly (fig. 1). TNF- $\alpha$, IL- 8 and IL-1 $\beta$ production by adherent cells reached the highest values at $48 \mathrm{~h}$ of culture: $1,417 \pm$ $1,128 \mathrm{pg} \cdot \mathrm{mL}^{-1}, 785 \pm 321 \mathrm{pg} \cdot \mathrm{mL}^{-1}$ and $94 \pm 153 \mathrm{pg} \cdot \mathrm{mL}^{-1}$, respectively. The production of TNF- $\alpha$ and eotaxin- 2 by nonadherent cells was also highest at $48 \mathrm{~h}$. Therefore, this time-point was used to monitor the production of inflammatory markers.

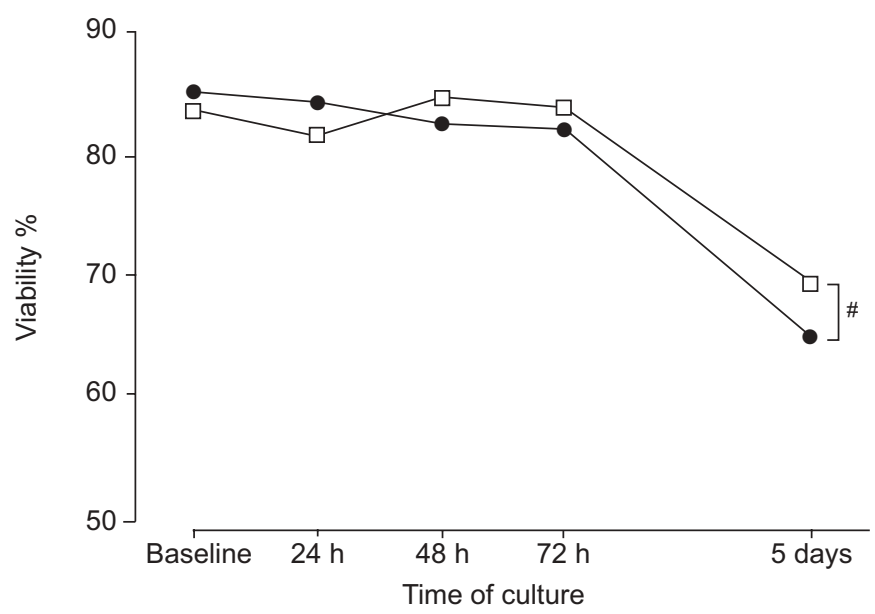

FIGURE 1. Viability of sputum cells in culture. Adherent $(\bullet)$ and nonadherent $(\square)$ cells were obtained from 21 asthmatic patients (asthma inhaled corticosteroid group) by sputum induction. ${ }^{*}: p=0.004$ in comparison with previous time-points for both adherent and nonadherent cells. 


\begin{tabular}{|c|c|c|c|}
\hline \multirow[t]{2}{*}{ TABLE 2} & \multicolumn{3}{|c|}{$\begin{array}{l}\text { Production of cytokines by lipopolysaccharide- } \\
\text { stimulated and nonstimulated adherent cells and } \\
\text { phytohaemaglutinin-stimulated and } \\
\text { nonstimulated nonadherent cells from induced } \\
\text { sputum in the asthma inhaled corticosteroids } \\
\text { group }\end{array}$} \\
\hline & & Nonstimulated & Stimulated \\
\hline \multicolumn{4}{|c|}{ Adherent cells } \\
\hline \multicolumn{2}{|c|}{$\mathrm{TNF}-\alpha \mathrm{pg} \cdot \mathrm{mL}^{-1}$} & $555 \pm 833$ & $816 \pm 1538$ \\
\hline \multicolumn{2}{|c|}{$\mathrm{IL}-8 \mathrm{pg} \cdot \mathrm{mL}^{-1}$} & $864 \pm 89$ & $826 \pm 35$ \\
\hline \multicolumn{2}{|c|}{$\mathrm{IL}-1 \beta \mathrm{pg} \cdot \mathrm{mL}^{-1}$} & $100 \pm 105$ & $89 \pm 94$ \\
\hline \multicolumn{4}{|c|}{ Nonadherent cells } \\
\hline \multicolumn{2}{|c|}{ Eotaxin-2 $\mathrm{pg} \cdot \mathrm{mL}^{-1}$} & $122 \pm 119$ & $115 \pm 101$ \\
\hline \multicolumn{2}{|c|}{$\mathrm{TNF}-\alpha \mathrm{pg} \cdot \mathrm{mL}^{-1}$} & $3637 \pm 2834$ & $3763 \pm 3364$ \\
\hline
\end{tabular}

Data are presented as mean \pm SD. TNF: tumour necrosis factor; IL: interleukin.

Cytokine levels with and without stimulation at the highest concentration of LPS or PHA were not statistically different (table 2). Cytokines produced by adherent and nonadherent cells in the comparison of asthma IC and control groups are shown in table 3 . The production of IL-13 by nonstimulated and stimulated nonadherent cells was below the detection limit of the assay.

\section{Effects of oral corticosteroid treatment}

Squamous cell percentage in induced sputum was $21.6 \pm 5.0 \%$ in the control group, $19.9 \pm 2.4 \%$ for the asthma OC group pretreatment, $28.4 \pm 5.1 \%$ for the asthma OC group post-treatment and $12.3 \pm 6.2 \%$ in the asthma IC group (nonsignificant differences). Differential cell counts of sputum, adherent and nonadherent cell cultures for all groups are shown in table 4 . Both asthma IC and OC groups had higher proportions of eosinophils at baseline in sputum and in the nonadherent fraction of the cell culture. A higher percentage of eosinophils was also detected in the adherent cell culture, especially in the asthma OC group at baseline.

The number of nonadherent cells at the end of $48 \mathrm{~h}$ of culture was similar among the groups $(p=0.92)$. The value for the control group was $2.8 \pm 3.0 \times 10^{4}$ cells $\cdot \mathrm{mL}^{-1}$, for patients treated with IC it was $2.4 \pm 1.2 \times 10^{4}$ cells $\cdot \mathrm{mL}^{-1}$ and for patients treated with OC it was $2.3 \pm 1.0 \times 10^{4}$ cells $\cdot \mathrm{mL}^{-1}$.

Eotaxin-2 production in culture of nonadherent cells (fig. 2) did not differ significantly between the control and asthma OC (posttreatment) groups $(\mathrm{p}=0.61)$. However, it differed significantly between asthma IC and control groups $(\mathrm{p}=0.03)$ and between asthma IC and asthma OC groups (post-treatment; $\mathrm{p}=0.04$ ). In the asthma OC group, values of eotaxin-2 concentration were $192 \pm 102 \mathrm{pg} \cdot \mathrm{mL}^{-1}$ (pre-treatment) and $30 \pm 30 \mathrm{pg} \cdot \mathrm{mL}^{-1}$ (posttreatment; $p=0.05)$. TNF- $\alpha$ production by nonadherent cells was $3,638 \pm 2,835 \mathrm{pg} \cdot \mathrm{mL}^{-1}$ in the pre-treatment phase of asthma OC group and $2,594 \pm 2,178 \mathrm{pg} \cdot \mathrm{mL}^{-1}$ in the post-treatment phase $(\mathrm{p}>0.05)$.

Sputum eotaxin-2 levels correlated with cell culture eotaxin-2 production $(\mathrm{r}=0.67 ; \mathrm{p}=0.04)$. The response to $\mathrm{OC}$ treatment was evaluated by calculating the difference between the levels

\begin{tabular}{|c|c|c|c|}
\hline \multirow[t]{2}{*}{ TABLE 3} & \multicolumn{3}{|c|}{$\begin{array}{l}\text { Production of cytokines by adherent cells and } \\
\text { nonadherent cells from induced sputum of the } \\
\text { control and asthma inhaled corticosteroids (IC) } \\
\text { groups }\end{array}$} \\
\hline & & Control group & Asthma IC group \\
\hline \multicolumn{4}{|c|}{ Adherent cells } \\
\hline TNF- $\alpha \mathrm{pg} \cdot \mathrm{n}$ & & $1817 \pm 901$ & $833 \pm 571$ \\
\hline $\mathrm{IL}-8 \mathrm{pg} \cdot \mathrm{mL}^{-}$ & & $889 \pm 13$ & $901 \pm 72$ \\
\hline $\mathrm{IL}-1 \beta \mathrm{pg} \cdot \mathrm{ml}$ & & $91 \pm 60$ & $94 \pm 62$ \\
\hline \multicolumn{4}{|c|}{ Nonadherent cells } \\
\hline Eotaxin-2 p & $m L^{-1}$ & $36 \pm 41$ & $131 \pm 108^{*}$ \\
\hline TNF- $\alpha \mathrm{pg} \cdot \mathrm{n}$ & & $1678 \pm 1976$ & $3778 \pm 276$ \\
\hline
\end{tabular}

of eotaxin-2 before and after prednisone treatment in induced sputum and in sputum cell culture (fig. 3 ). The response was greater in cell culture, $134 \pm 80 \mathrm{pg} \cdot \mathrm{mL}^{-1}$, than in induced sputum, $23 \pm 33 \mathrm{pg} \cdot \mathrm{mL}^{-1}(\mathrm{p}=0.04)$.

The blood eosinophil count in the asthma OC group fell from the pre-treatment, $8.6 \pm 4.8 \%$, to the post-treatment period, $1.5 \pm 1.6 \% \quad(p=0.002)$. The pre-treatment blood eosinophil number correlated with eotaxin-2 production by cell culture

\begin{tabular}{|c|c|c|c|c|}
\hline \multirow{2}{*}{ TABLE 4} & \multirow[t]{2}{*}{ Control } & \multirow[t]{2}{*}{ Asthma IC } & \multicolumn{2}{|c|}{ Asthma OC } \\
\hline & & & $\begin{array}{l}\text { Pre- } \\
\text { treatment }\end{array}$ & $\begin{array}{l}\text { Post- } \\
\text { treatment }\end{array}$ \\
\hline \multicolumn{5}{|l|}{ Eosinophils \% } \\
\hline Sputum & $1.8 \pm 3.2$ & $25.7 \pm 31.2^{\#}$ & $11.2 \pm 12.1^{\#}$ & $0.8 \pm 1.4$ \\
\hline Adherent cells & $0.2 \pm 0.5$ & $8.7 \pm 11.8$ & $9.2 \pm 6.8^{\circ}$ & $0.9 \pm 1.4$ \\
\hline Nonadherent cells & 0 & $23.8 \pm 32.9^{\circ}$ & $17.1 \pm 6.3^{\circ}$ & $1.6 \pm 1.8$ \\
\hline \multicolumn{5}{|l|}{ Lymphocytes \% } \\
\hline Sputum & $16.1 \pm 13.0$ & $4.5 \pm 1.5^{\circ}$ & $8.6 \pm 3.7$ & $5.8 \pm 2.5$ \\
\hline Adherent cells & $19.8 \pm 7.7$ & $9.8 \pm 1.7$ & $31.0 \pm 26.1$ & $1.6 \pm 2.2$ \\
\hline Nonadherent cells & $3.6 \pm 4.2$ & $6.2 \pm 7.3$ & $17.6 \pm 15.6^{\circ}$ & $7.0 \pm 6.5$ \\
\hline \multicolumn{5}{|l|}{ Neutrophils \% } \\
\hline Sputum & $38.4 \pm 21.6$ & $22.3 \pm 9.2^{+}$ & $54.1 \pm 20.6$ & $66.9 \pm 9.2^{\bullet}$ \\
\hline Adherent cells & $0.5 \pm 1.0$ & $0.8 \pm 1.3$ & $25.0 \pm 23.1^{\circ}$ & $3.2 \pm 4.5$ \\
\hline Nonadherent cells & $0.6 \pm 1.2$ & 0 & $33.6 \pm 28.3$ & $2.0 \pm 0.2$ \\
\hline \multicolumn{5}{|l|}{ Macrophages \% } \\
\hline Sputum & $43.6 \pm 22.9$ & $53.6 \pm 23.9^{5}$ & $34.7 \pm 17.3$ & $26.5 \pm 20.2$ \\
\hline Adherent cells & $79.8 \pm 9.1$ & $80.4 \pm 12.1$ & $40.1 \pm 14.6^{\circ}$ & $94.0 \pm 6.1$ \\
\hline Nonadherent cells & $91.4 \pm 26.4$ & $70.0 \pm 38.1$ & $31.6 \pm 7.4$ & $88.6 \pm 7.9$ \\
\hline
\end{tabular}

Data are presented as mean $\pm \mathrm{SD}$. IC: inhaled corticosteroids; OC: oral corticosteroids. ${ }^{\#:} \mathrm{p}<0.05$ compared with asthma OC post-treatment and control group; ": $p<0.05$ compared with control group; ${ }^{+}: p<0.05$ compared with asthma OC pre- and post-treatment; ${ }^{s}$ : $p<0.05$ compared with asthma OC post-treatment. 


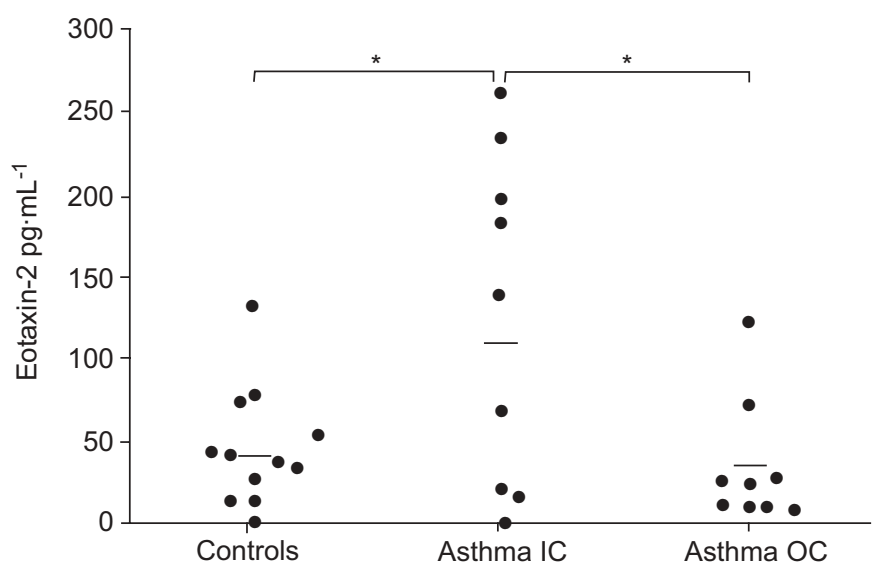

FIGURE 2. Production of eotaxin-2 by sputum cell culture (nonadherent cells) of normal subjects (controls), asthmatics treated with an inhaled corticosteroid (IC), and asthmatics treated with an oral corticosteroid $(\mathrm{OC})$. The horizontal bars indicate means of values. ${ }^{*}: p<0.05$

$(\mathrm{r}=0.71 ; \mathrm{p}=0.02)$. The response in cell culture eotaxin-2 production to steroid treatment correlated with the response in blood eosinophil number and sputum eosinophil number $(\mathrm{r}=0.74 ; \mathrm{p}=0.04)$. Sputum eosinophil number correlated with eotaxin-2 level in sputum $(r=0.56 ; p=0.01)$ but not with eotaxin-2 production by cell culture.

\section{DISCUSSION}

In the present study, the possibility of evaluating in vitro the inflammatory status of asthmatic patients has been shown. The present authors cultured sputum inflammatory cells of asthmatic and normal subjects. In the few studies that tried to keep sputum cells in culture to evaluate the inflammatory characteristics of asthma, sputum cells were cultured without fractionation [18-22]. The cells were separated into two fractions, adherent and nonadherent, and cytokines, chemokines and cell composition were evaluated in each fraction. In the culture of adherent cells, TNF- $\alpha$, IL- 8 and IL- $1 \beta$ were detected from both the asthma and control groups. In the culture of nonadherent cells, eotaxin- 1 and -2 , and TNF- $\alpha$ were detected. Of the measured mediators, eotaxin-2 appeared to show the greatest differences between the various groups. Indeed, eotaxin-2 production was higher in the asthma group compared to the control group and treatment with OC abolished this difference. In addition, reduction of eotaxin-2 levels by this treatment was greater in cell culture than in sputum.

The present study was the first to evaluate and detect eotaxin-2 in sputum and sputum cell culture of asthmatic patients. The first eotaxin was discovered using a guinea pig model of allergic airway disease characterised by marked lung eosinophilia [26, 27]. In humans, MATTOLI et al. [28] showed that the numbers of cells expressing mRNA for eotaxin-1 correlated significantly with the number of eosinophils, bronchial hyperreactivity and symptom score in asthmatics. Furthermore, increased eotaxin-1 protein has been detected in the BAL fluid of asthmatic subjects [29]. According to Міотто et al. [10], eotaxin-1 is selectively increased in Th2-mediated airway diseases and this chemokine

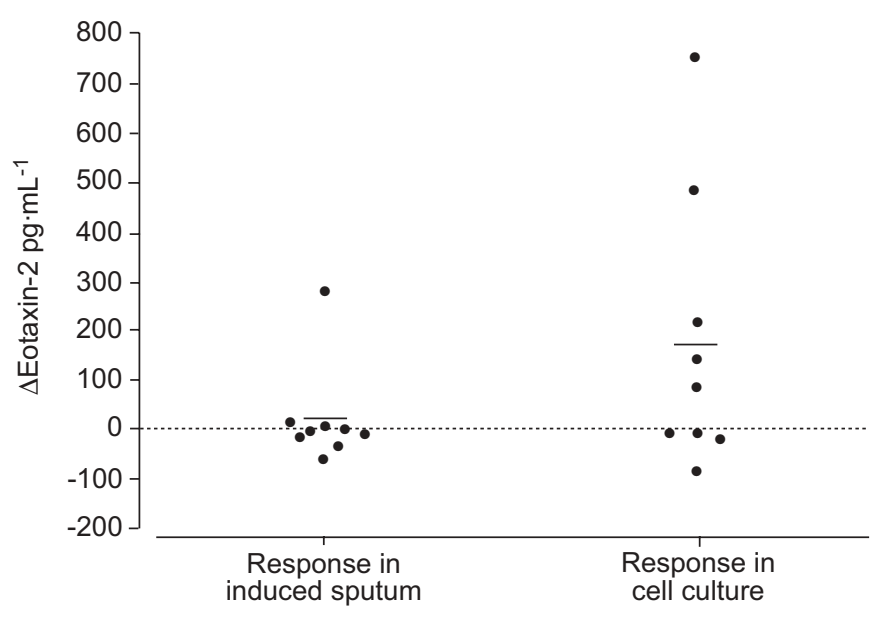

FIGURE 3. Response to corticosteroid treatment was measured as change $(\Delta)$ in production of eotaxin-2 ( $\Delta$ eotaxin-2=eotaxin-2 pre-treatment-eotaxin-2 posttreatment) tested in both induced sputum and sputum cell culture (nonadherent cells). Asthmatics were treated with oral prednisone $40 \mathrm{mg} \cdot$ day $^{-1}$ for 14 days. The horizontal bars indicate means of values. There was a significant difference between response in cell culture and response in induced sputum $(p=0.04)$.

plays a central role in the pathogenesis of asthma. In addition to stimulating eosinophil chemotaxis, eotaxin-1 induces aggregation of eosinophils, an elevation in their intracellular calcium levels [29] and respiratory burst activity. Similarly to eotaxin-1, eotaxin-2 is known to be a potent eosinophil chemoattractant in vitro and in vivo [30-32]. A study of the late-phase allergic reactions in the skin of human atopic subjects suggested that eotaxin-1 is involved in the early 6-h recruitment of eosinophils, whereas eotaxin-2 is involved in the later 24 -h infiltration of these cells [32].

The present findings demonstrate a relationship between eotaxin-2 and asthma. Eotaxin-2 production in cell culture correlated with eosinophil number in peripheral blood, and eotaxin-2 concentration in sputum correlated with eosinophil number in sputum. Furthermore, the decrease in eotaxin-2 production induced by systemic steroid treatment was associated with the decrease in eosinophil number in sputum and blood. In culture, eotaxin-2 levels of patients treated with IC were significantly higher than those of controls and patients treated with OC. This may indicate that the inflammatory status of patients treated with regular IC remains high. The detected percentage of eosinophils in sputum corroborates this theory. In a study on mild asthma, JATAKANON et al. [33] evaluated the effect of differing doses of inhaled budesonide on airway inflammation markers. JATAKANON et al. [33] showed a significant trend towards greater reduction in inflammatory markers with higher dose of budesonide $\left(1,600 \mu \mathrm{g} \cdot\right.$ day $\left.^{-1}\right)$, suggesting a dose-dependent effect of inhaled steroids on airway inflammation. The elevated concentration of eotaxin-2 found in the present study may have been due to the fact that most asthmatic patients were treated with a low-dose IC. In contrast, there was no significant difference in eotaxin-2 levels between patients treated with OC and controls. The effectiveness of OC in the treatment of chronic asthma (OC are the most potent anti-inflammatory drugs used in the treatment 
of asthma) probably results from a combination of antiinflammatory actions [34], which inhibit gene transcription of the majority of cytokines involved in asthmatic airway inflammation [35-37].

With regard to the constitution of sputum cell cultures, asthmatic patients had a higher proportion of eosinophils in all fractions at baseline. In the post-treatment evaluation, those numbers of eosinophils fell to values that were not different from the control group values. The proportion of macrophages increased from the time of sputum collection to the end of cell culture period in both adherent and nonadherent fractions, which may represent cell proliferation in culture. Further studies are necessary to evaluate the mechanisms of cell number changes and to determine whether the decrease in eotaxin production reflects changes in cell number or suppression by steroid effect.

A series of spike and recovery experiments with eotaxin-2 have been performed (data not shown). The results observed clearly demonstrate that the processing of samples with DTT diminishes the recovery of the chemokine in sputum samples by $\sim 50-60 \%$. It is noteworthy, however, that the effect of DTT on the samples was linear in the range $30-300 \mathrm{pg} \cdot \mathrm{ml}^{-1}$ of eotaxin-2 in sputum. This means that the effect of DTT on eotaxin-2 determination was similar in all the samples and that the processing itself was not responsible for the differences observed between the various groups of patients. These data confirmed observations reported in previous studies [38].

The interference of DTT on eotaxin-2 measurements may explain, at least partially, the advantage of cell culture supernatant over sputum supernatant. Sputum cell culture supernatant has no DTT and eotaxin-2 is produced de novo. Thus, the assay to measure mediators in culture supernatant is free of the DTT interference, which may account for the superior performance of sputum cell culture in detecting a response to patient treatment.

The cytokines and chemokines could be detected in vitro without any additional stimulus in the culture medium. The results demonstrated no significant difference in inflammatory markers with stimulation of the adherent and nonadherent cells with LPS or PHA, respectively. The present results are consistent with the cells being activated during their migration to the airway and agree with those of BETTIOL et al. [18]. Conversely, LiU et al. [19] had to add PHA in order to obtain detectable levels of interferon- $\gamma$ in their sputum cell culture.

In conclusion, the present study demonstrates the usefulness of in vitro sputum cell generation of cytokines and chemokines as a suitable model to evaluate the airway inflammation observed in asthmatic patients. The present findings show a correlation between eotaxin-2 production in cell culture and eosinophil number in peripheral blood or sputum. In addition, there was a greater fall in eotaxin-2 levels measured in cell culture than in induced sputum following treatment. Overall, the present results suggest that analysis of sputum cell culture is sensitive for the detection of the effects of anti-inflammatory drugs and are consistent with an important role of eotaxin- 2 in the pathophysiology of asthma.

\section{REFERENCES}

1 Spahn J, Covar R, Stempel DA. Asthma: addressing consistency in results from basic science, clinical trials, and observational experience. J Allergy Clin Immunol 2002; 109: Suppl. 5, 490S-502S.

2 Maddox L, Schwartz DA. The pathophysiology of asthma. Annu Rev Med 2002; 53: 477-498.

3 Zlotnik A, Yoshie O. Chemokines: a new classification system and their role in immunity. Immunity 2000; 12: 121-127.

4 Teran LM. CCL chemokines and asthma. Immunol Today 2000; 21: 235-242.

5 Rojas-Ramos E, Avalos AF, Perez-Fernandez L, CuevasSchacht F, Valencia-Maqueda E, Teran LM. Role of the chemokines RANTES, monocyte chemotactic proteins-3 and -4 , and eotaxins- 1 and -2 in childhood asthma. Eur Respir J 2003; 22: 310-316.

6 Ying S, Meng O, Zeibecoglou K, et al. Eosinophil chemotactic chemokines (eotaxin, eotaxin-2, RANTES, monocyte chemoattractant protein-3 (MCP-3), and MCP4 ), and C-C chemokine receptor 3 expression in bronchial biopsies from atopic and nonatopic (Intrinsic) asthmatics. $J$ Immunol 1999; 163: 6321-6329.

7 Teran LM, Noso N, Carroll M, Davies DE, Holgate S, Schroeder JM. Eosinophil recruitment following allergen challenge is associated with the release of the chemokine RANTES into asthmatic airway. J Immunol 1996; 157: 1806-1812.

8 Lamkhioued B, Renzi PM, Abi-Younes S, et al. Increased expression of eotaxin in bronchoalveolar lavage and airways of asthmatics contributes to the chemotaxis of eosinophils to the site of inflammation. J Immunol 1997; 159: 4593-4601.

9 Lamkhioued B, Garcia-Zepeda EA, Abi-Younes S, et al. Monocyte chemoattractant protein (MCP)-4 expression in the airways of patients with asthma. Induction in epithelial cells and mononuclear cells by proinflammatory cytokines. Am J Respir Crit Care Med 2000; 162: 723-732.

10 Miotto D, Christodoulopoulos P, Olivenstein R, et al. Expression of IFN- $\gamma$-inducible protein; monocyte chemotactic proteins 1, 3, and 4; and eotaxin in Th1- and Th2mediated lung diseases. J Allergy Clin Immunol 2001; 107: 664-670.

11 Vignola AM, Rennard SI, Hargrave FE, et al. Standardised methodology of sputum induction and processing. Future directions. Eur Respir J 2002; 20: Suppl. 37, 51S-55S.

12 Kips JC, Inman MD, Jayaram L, et al. The use of induced sputum in clinical trials. Eur Respir J 2002; 20: Suppl. 37, 47S-50S.

13 Djukanovic R, Sterk PJ, Fahy JV, Hargreave FE. Standardised methodology of sputum induction and processing. Eur Respir J 2002; 20: Suppl. 37, 1S-2S.

14 Pin I, Gibson PG, Kolendowicz R, et al. Use of induced sputum cell counts to investigate airway inflammation in asthma. Thorax 1992; 47: 25-29.

15 Corrigan CJ, Bungre JK, Assoufi B, Cooper AE, Seddon H, Kay AB. Glucocorticoid resistant asthma: T-lymphocyte steroid metabolism and sensitivity to glucocorticoids and immunosuppressive agents. Eur Respir J 1996; 9: 2077-2086.

16 Vianna EO, Westcott J, Martin RJ. The effects of upper respiratory infection on $\mathrm{T}$-cell proliferation and steroid 
sensitivity of asthmatics. J Allergy Clin Immunol 1998; 102: 592-597.

17 Kraft M, Vianna E, Martin RJ, Leung DY. Nocturnal asthma is associated with reduced glucocorticoid receptor binding affinity and decreased steroid responsiveness at night. J Allergy Clin Immunol 1999; 103: 66-71.

18 Bettiol J, Sele J, Henket M, et al. Cytokine production from sputum cells after allergenic challenge in IgE-mediated asthma. Allergy 2002; 57: 1145-1150.

19 Liu LY, Swensen CA, Kelly EA, Kita H, Busse WW. The relationship of sputum eosinophilia and sputum cell generation of IL-5. J Allergy Clin Immunol 2000; 106: 1063-1069.

20 Komai-Koma M, McKay A, Thomson L, et al. Immunoregulatory cytokines in asthma: IL-15 and IL-13 in induced sputum. Clin Exp Allergy 2001; 31: 1441-1448.

21 Hamzaoui A, Brahim MB, Zhioua A, Ayed K, Hamzaoui K. Inflammatory response in induced sputum mononuclear cells from patients with acute exacerbation of asthma. Mediators Inflamm 2000; 9: 147-153.

22 Boniface S, Koscher V, Mamessier E, et al. Assessment of T lymphocyte cytokine production in induced sputum from asthmatics: a flow cytometry study. Clin Exp Allergy 2003; 33: $1238-1243$.

23 ACCP-ATS Joint Committee on Pulmonary Nomenclature, Pulmonary terms and symbols. Chest 1975; 67: 5833-5893.

24 Paggiaro PL, Chanez $\mathrm{P}, \mathrm{Holz} \mathrm{O}$, et al. Sputum induction. Eur Respir J 2002; 20: Suppl. 37, 3S-8S.

25 Pizzichini E, Pizzichini MM, Leigh R, Djukanovic R, Sterk PJ. Safety of sputum induction. Eur Respir J 2002; 20: Suppl. 37, 9S-18S.

26 Griffiths-Johnson DA, Collins PD, Rossi AG, Jose PJ, Willians TJ. The chemokine, eotaxin, activates guinea-pig eosinophils in vitro and causes their accumulation into the lung in vivo. Biochem Biophys Res Commun 1993; 197: 1167-1172.

27 Jose PJ, Griffiths-Johnson DA, Collins PD, et al. Eotaxin: a potent eosinophil chemoattractant cytokine detected in a guineapig model of allergic airways inflammation. J Exp Med 1994; 179: 881-887.
28 Mattoli S, Stacey MA, Sun G, Bellini A, Marini M. Eotaxin expression and eosinophilic inflammation in asthma. Biochem Biophys Res Commun 1997; 236: 299-301.

29 Rankin SM, Conroy DM, Williams TJ. Eotaxin and eosinophil recruitment: implications for human disease. Mol Med Today 2000; 6: 20-27.

30 Forssmann U, Uguccioni M, Loetscher $\mathrm{P}$, et al. Eotaxin-2, a novel CC chemokine that is selective for the chemokine receptor CCR3, and acts like eotaxin on human eosinophil and basophil leukocytes. J Exp Med 1997; 185: 2171-2176.

31 White JR, Imburgia C, Dul E, et al. Cloning and functional characterization of a novel human CC chemokine that binds to the CCR3 receptor and activates human eosinophil. J Leukoc Biol 1997; 62: 667-675.

32 Ying S, Robinson DS, Meng O, et al. CC chemokines in allergen-induced late-phase cutaneous responses in atopic subjects: association of eotaxin with early 6-hour eosinophils, and of eotaxin-2 and monocyte chemoattractant protein-4 with the later 24-hour tissue eosinophilia, and relationship to basophils and other CC chemokines (monocyte chemoattractant protein-3 and RANTES). J Immunol 1999; 163: 3976-3984.

33 Jatakanon A, Kharitonov S, Lim S, Barnes PJ. Effect of differing doses of inhaled budesonide on markers of airway inflammation in patients with mild asthma. Thorax 1999; 54: 108-114.

34 Leung DY, De Castro M, Szefler SJ, Chrousos GP. Mechanisms of glucocorticoid-resistant asthma. Ann NY Acad Sci 1998; 840: 735-746.

35 Walsh SD, Grant IWB. Corticosteroids in the treatment of asthma. BMJ 1966; 2: 796-807.

36 Mukaida N, Morita M, Ishikawa Y, et al. Novel mechanism of glucocorticoid-mediated gene repression. Nuclear factor-kappa B is target for glucocorticoid-mediated interleukin-8 gene repression. J Biol Chem 1994; 269: 13289-13295.

37 Kelley J. Cytokines of the lung. Am Rev Respir Dis 1990; 141: 765-788.

38 Hadjicharalambous C, Dent G, May RD, et al. Measurement of eotaxin (CCL11) in induced sputum supernatants: validation and detection in asthma. $J$ Allergy Clin Immunol 2004; 113: 657-662. 